PRI MCED Discussion Paper Series, No. 30

\title{
Productivity Change and Mine Dynamics: The Coal Industry in Japan during World War II
}

\author{
Tetsuji Okazaki
}

November 2012 


\title{
Productivity Change and Mine Dynamics: The Coal Industry in Japan during World War II
}

\author{
Tetsuji Okazaki（The University of Tokyo）
}

\begin{abstract}
In the 1930s and 1940s, the Japanese coal industry experienced huge fluctuations in production and labor productivity. In this paper, I explore the micro-aspects of labor productivity change in the coal industry during World War II, using mine-level data compiled from official statistics and original documents of the Coal Control Association (Sekitan Toseikai). The coal industry in this period was characterized by dynamic changes in market structure: a number of mines entered and exited the industry, and shares of incumbent mines changed substantially. These mine dynamics had substantial productivity implications. In the early stage of the war, many low productivity mines entered the industry, which reduced average labor productivity considerably. The government and the Coal Control Association implemented a policy to concentrate resources and production on efficient mines during the war, which curbed the decline in average labor productivity. Despite the deteriorating environment during the war, coal production in Japan was maintained fairly well. One of the factors that made this possible was the policy of resource reallocation.
\end{abstract}

Key words: Productivity, producer dynamics, war economy, coal, Japan JEL Classification Numbers: L11, L52, L71, N45, N75, N85 


\section{Introduction}

The Japanese economy, which had been growing steadily since the late nineteenth century, suddenly ceased to grow after 1937, when a full-scale war with China broke out. Indeed, the average annual growth rate of real GNP in the period from 1937 to 1944 was $-0.41 \%$. However, it should be noted that the environment of the Japanese economy deteriorated tremendously in this period. A blockade and restriction on international trade caused real imports to Japan to be $47 \%$ smaller in 1944 than that in 1937 (Bank of Japan 1966, p. 51). This raises the question of how Japan was able to maintain production in this deteriorating environment.

One of the basic conditions that enabled the Japanese economy to withstand the blockade was that it was almost self-sufficient in energy throughout this period. Japan was richly endowed with coal, which was the major source of energy until the postwar high growth period, when petroleum took over that position. Coal accounted for $62.2 \%$ and $58.8 \%$ of the total energy supply in 1935 and 1944, respectively (Toko Keizai Shinposha 1991, p. 449). Therefore, the coal industry was regarded as being of strategic importance.

As we will see below, coal production in Japan experienced huge fluctuations in the 1930s and 1940s, as well as substantial changes in labor productivity. In this paper, I explore the micro-aspects of these productivity changes. Focusing on the micro-aspects is particularly important in analyzing the coal industry during the war, because the government implemented a policy to concentrate production and resources on efficient mines, which induced substantial changes in the market structure. To investigate the micro-aspects, I use mine-level data on coal production and labor input. Reflecting the strategic importance of the coal industry, comprehensive mine-level data were officially recorded. For the time the official statistics are not available, I use data collected by the industrial association (Coal Control Association, Sekitan Toseikai).

Since the seminal work of Dunne et al. (1988, 1989), producer dynamics has been one of the major issues in industrial studies, given the increasing availability of comprehensive plant-level data. In the same vein, a number of studies have investigated the productivity implications of producer dynamics (Baily et al. 1992; Griliches and Regev 1995; Ellerman et al. 2001; Foster et al. 2001). In this paper, I apply the methodology and insights developed in this growing literature to a historical study of the micro-aspects of the war economy in Japan.

The remainder of the paper is organized as follows. Section 2 overviews the Japanese coal industry and the government coal policy during World War II. In Section 3, I analyze labor productivity at the district-level. Section 4 describes the mine 
dynamics and investigates the implications for labor productivity change. Section 5 concludes the paper.

\section{Overview of the coal industry during World War II}

Figure 1 depicts the time series of production and labor productivity in the Japanese coal industry from the early 1930s to the end of the war. Labor productivity is measured by production per worker. We can identify some phases in this figure. Coal production increased from the early 1930s until 1940, when it reached a plateau; it was maintained at this high level until 1944, in the final stage of the war. In 1945, it declined sharply. Labor productivity behaved rather differently from production: it reached its peak as early as 1933, and then continued to decline until 1945 .

\section{Figure 1}

An important regime change took place in the general economic system around the middle of the phase of increasing coal production. The starting point of the regime change was the acceleration of inflation and the sharp increase in imports from the end of 1936, caused by the announcement of the huge expansion of the military budget. To restrict imports, the government imposed direct control on use of foreign exchange. In addition to the short-term increase in the military budget, the army drew up a long-term expansion plan for munitions industries including coal, steel and machine tools (Five Year Plan for Important Industries, Juyo Sangyo Gokanen Keikaku), and requested the government to implement it in May 1937, just before the Sino-Japanese War.

When the full-scale war with China began in July 1937, the government expanded its economic controls to mobilize resources for the war. In 1938, the government drew up a plan for allocating strategic commodities including coal and steel (Material Mobilization Plan, Busshi Doin Keikaku), and imposed controls on production and distribution of those commodities to implement the plan. At the same time, price controls were also introduced. That is, in August 1938, the Commodity Price Control Rule (Buppin Hanbai Kakaku Torihismari Kisoku) was enacted to authorize the government the authority to enforce an upper-bound price for each commodity. As a long-term plan for expanding munitions industries, the Four Year Plan for Production Capacity Expansion (Seisanryoku Kakuju Keikaku), was set by the Cabinet in January 1939. Thus, the basic system of planning and control was established by 1939 (Okazaki 1987; Okazaki and Okuno-Fujiwara 1999). 
The coal industry was substantially affected by this general regime change. In early 1937, the government requested the Coal Mining Association (Sekitan Kogyo Rengokai) to make a five year plan for production expansion. In response, the Coal Mining Association made a five year forecast on coal demand and supply, which the government referred to in drawing up its Four Year Plan (Table 1). Control of coal prices was introduced in September 1938, when the government ordered Showa Coal Co. (Showa Sekitan), the joint sales company of the Coal Mining Association, to reduce coal prices by $10 \%$. However, prices set by smaller mines that were not members of the Coal Mining Association, were not strictly controlled; this stimulated entry of smaller mines. To resolve this problem, a new joint sales company, Nihon Coal Co. (Nihon Sekitan), was established in May 1940, taking the place of Showa Coal Co.. Using government subsidies, Nihon Coal Co. purchased all the coal produced in Japan at a price covering the production cost of each mine, which was pooled to be sold at the official price (Nezu ed. 1958). Subsequently, differences between the average purchasing price (price for producer) and selling price (price for consumer) of Nihon Coal Co. widened, thus giving coal mines incentives for increasing production as well as curbing inflation (Figure 2).

Table 1, Figure 2

The year 1940 was a turning point for the whole Japanese war economy, as well as for the coal industry. In September 1940, the diplomatic conflict with the U.S. reached its decisive point because of Japan's invasion of northern Indochina and its military alliance with Germany and Italy. The U.S. responded by placing an embargo on steel scrap trade with Japan, which had a substantial impact on Japan's munitions production. To cope with this change prepare for the war with the U.S. expected in the near future, the Japanese government tried to strengthen the war economy. One of the key reform measures was to establish powerful industrial associations (control association, toseikai) in strategic industries, including coal and steel. In principle, each control association would organize all the companies in the industry, and the president of the association was granted wide-ranging authority to command member companies, under the Major Industrial Association Directive (Juyo Sangyo Dantai ReI) (Okazaki and Okuno-Fujiwara 1999).

The Coal Control Association (Sekitan Toseikai) was founded in November 1941. It played an essential role in drawing up and implementing mine-level production plans and other policies for the coal industry. The following month, in December 1941, war with the U.S. (Pacific War) broke out. Mobilization of resources for the war restricted 
the supply of materials, particularly steel, to the coal industry. Consequently, steel-labor ratio in the coal industry declined sharply from 1940 (Figure 3).

Figure 3

Under these conditions, the government and the Coal Control Association adopted a policy to concentrate resources and production on efficient mines. As a result, inefficient mines were closed and workers were moved to more efficient mines. This selective policy was continued until the final stages of the war (Nezu ed. 1958).

\section{Productivity change and its sources: District-level analysis}

To investigate the implication of these policies for productivity, we first look at district-level data. Five government bureaus were responsible for supervising mines: Sapporo, Sendai, Tokyo, Osaka and Fukuoka. Each bureau was responsible for between one and three districts (Sapporo: Hokkaido; Sendai: Tohoku; Tokyo: Kanto and Chubu; Osaka: Kinki; Chugoku except Yamaguchi Prefecture; Fukuoka: Kyushu, Yamaguchi Prefecture and Okinawa Prefecture). A series of official statistics, Honpo Kogyo no Susei (Trends of the Japanese Mining Industry), released by the Ministry of Commerce and Industry contains production and input data for the jurisdiction of each mine supervision bureau. Here, we refer to these data as district-level data, for simplicity.

Table 2 summarizes the data for four time points: 1930, 1935, 1939 and 1944. As shown, more than $90 \%$ of coal was produced in two districts, Sapporo (Hokkaido) and Fukuoka (Kyushu). Of these two districts, production in Kyushu was much larger, but its share declined during the war. Indeed, coal mines in Kyushu were aging, whereas those in Hokkaido were newly developed. Labor productivity varied substantially across districts, and was substantially higher in Hokkaido than elsewhere. Finally, over time changes in labor productivity were similar across districts: generally it rose from 1930 to 1935 , and then declined. This is similar to the change in the aggregate labor productivity indicated in Figure 1.

Table 2

It is possible to analyze cross-sectional and time series variation in labor productivity by regression analysis. To do that, the following standard Cobb-Douglas type production function is assumed. 
$\mathrm{Y}_{\mathrm{it}}=\mathrm{A}^{*}$ STEEL $_{\mathrm{it}}{ }^{\alpha *} \operatorname{EXPLOSIVE}_{\mathrm{it}}{ }^{\beta *} \operatorname{ELECTLICITY}_{\mathrm{it}}{ }^{\gamma *} \mathrm{Lit}^{1{ }^{-\alpha-\beta-\gamma}}$

Y: Coal production

STEEL: Steel inputs

EXPLOSIVE: Explosive inputs

ELRCYLICITY: Electricity inputs

L: Number of workers

i : District index

$\mathrm{t}$ : Year index

Then, labor productivity is,

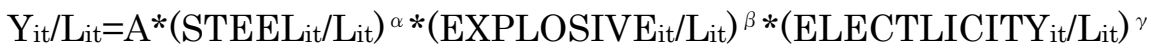

Taking the log and adding district dummies $\left(\delta_{i}\right)$ and year dummies $\left(\lambda_{t}\right)$ to control for district specific shocks and macro shocks on labor productivity, as well as an error term $(\varepsilon$ it), we have

$\ln \left(\mathrm{Y}_{\mathrm{it}} / \mathrm{L}_{\mathrm{it}}\right)=\ln \mathrm{A}+\alpha \ln \left(\right.$ STEEL $\left._{\mathrm{it}} / \mathrm{L}_{\mathrm{it}}\right)+\beta \ln \left(\right.$ EXPLOSIVE $\left._{\mathrm{it}} / \mathrm{L}_{\mathrm{it}}\right)+\gamma \ln \left(\right.$ ELECTRICITY $\left._{\mathrm{it}} / \mathrm{L}_{\mathrm{it}}\right)$ $+\delta_{i}+\lambda_{t}+\varepsilon$ it

Using the annual data from 1930 to 1944, we estimate equation (3). The observations are 75 district-year ( 5 districts * 15 years). The basic statistics and the estimation result are reported in Table 3 and Table 4.

Table 3, Table 4

A couple of interesting findings emerge. District dummies represent districtspecific total factor productivity (TFP) levels. With Hokkaido as the reference, all of the district dummies are negative, and they are statistically significant except in Tokyo. This implies that the higher labor productivity in Hokkaido observed in Table 2 reflects higher TFP there. Also, remarkable is the fairly large size of the difference. For example, the difference in TFP between Hokkaido and Kyushu equals to 0.68 standard deviations of labor productivity for the total observations. Similarly, year dummies represent yearspecific TFP levels. The results indicate that TFP changed systematically over time. That is, TFP declined gradually from 1931 to 1934, and stayed almost constant until 1936, when it started to decline again; however, from 1939 the pace of decline slowed to 
become moderate.

Based on the estimates in Table 4, we can decompose the labor productivity change into contributions of input-labor ratios and TFP using the following formula.

$$
\begin{aligned}
& \Delta \ln \left(Y_{t} / L_{t}\right)=\hat{\alpha} \Delta \sum_{i} \ln \left(S T E E L_{i t} / L_{i t}\right) * w_{i t}+\hat{\beta} \Delta \sum_{i} \ln \left(\text { EXPLOSIVE } E_{i t} / L_{i t}\right) * w_{i t} \\
& +\hat{\gamma} \Delta \sum_{i} \ln \left(E L E C T R I C I T Y_{i t} / L_{i t}\right) * w_{i t}+\Delta \sum_{i} \hat{\delta}_{i}^{*} w_{i t}+\Delta \hat{\lambda}_{t}
\end{aligned}
$$

where $\Delta$ denotes a lag operator, and wit denotes the weight of district $\mathrm{i}$ in year $\mathrm{t}$.

Table 5 decomposes the average labor productivity using two alternative wit, number of workers and coal production. The results are qualitatively the same. Before the war (1930-35), there were two major sources of labor productivity improvement, namely increase in the input-labor ratio and TFP growth; the start of the war affected both of these sources. During 1935-39, the contribution of input-labor ratio fell to almost zero, and TFP declined substantially to become negative. In the late stage of the war, 1939-44, the contribution of the input-labor ratio, particularly the contribution of steel-labor ratio, became negative. This reflects the restriction of steel supply, as discussed in the previous section. On the other hand, it is remarkable that the magnitude of the negative impact of TFP decreased under the deteriorating conditions in the coal industry. In the next section, I use mine-level data to explore the cause of large TFP decline and efforts to mitigate it in the early and late stages of the war.

\section{Table 5}

\section{Mine dynamics and productivity change}

As mentioned in Section 2, the government and the Coal Control Association cut off resources to inefficient coal mines and closed them, with the aim of concentrating production on efficient mines. As a result mine dynamics in this period was related to a key policy issue. To see the scale of mine dynamics and its productivity implications, we need comprehensive mine-level data on production and inputs. For this purpose also, the basic data source is Honpo Kogyo no Susei (Trends of the Japanese Mining Industry), which contains mine-level data on production and numbers of workers for almost all coal mines with an annual production over 10,000 tons. Unfortunately, input data on factors other than workers are not available, so mine-level TFP cannot be measured. Nevertheless, using these data does male it possible to observe mine dynamics and the implications for labor productivity. 
For this analysis, I use the 1930, 1935 and 1939-40 issues of Honpo Kogyo no Susei. Because the issue covering 1941-1945, lacks data on workers, we obtained the data for 1944 from the original Coal Control Association records, held at the Ibaraki Prefectural Museum of History1. A document entitled "Tanko Ichiranhyo" (List of Coal Mines) by the Labor Department of the Coal Control Association, contains mine-level data on coal production and number of workers for August 1944.

Using these data, we now examine the entry and exit of coal mines. Table 6 reports entry and exit for three periods: $1930-35,1935-39$, and 1939-44. First, let us look at the period 1930-35, just before the war, as a benchmark. In 1930, there were 156 coal mines whose annual production was over 10,000 tons. Thirty five of these had exited by 1935 . These exiting mines accounted for $22.4 \%$ of the total in terms of number of mines, but only $6.5 \%$ in terms of production. During the same period, 76 new mines entered the industry, with a production share of $9.1 \%$ in 1935 . These data imply that despite the frequency of entry and exit, most of these mines were small; hence market structure remained basically stable in this period.

Table 6

By contrast, the period 1935 - 39, the early stage of the war, was characterized by accelerations of entry. That is, 144 mines entered the industry and their production share was $14.2 \%$. This is attributable to the growth of military demand and the sharp rise in coal prices from the end of 1936 (Figure 2). New entries were also encouraged by the price control policy that excluded smaller mines that were not the members of the Coal Mining Association (Sekitan Kogyo Rengokai). On the other hand, exit did not change substantially.

In 1939-44, the landscape changed again. This period, the late stage of the war, was characterized by a surge in exit and a decline in entry. Indeed, 142 mines with a total production share of $14.1 \%$, exited, whereas the new entrants had a share of just $7.3 \%$ in 1944. This reflects the policy of concentrating resources and production on efficient mines and to close inefficient mines, discussed above.

The wartime policy of concentrating production on efficient coal mines was based on the belief that the productivity varied greatly across mines, and this was indeed the case. Table 7 summarizes the basic statistics of each coal mine's labor productivity. For example, in 1939, average labor productivity was 164.0 tons per worker, with a

\footnotetext{
1 These documents were originally held by an ex-staff member of the Coal Control Association.
} 
standard deviation was 82.4 , which is around half the average. As the maximum and minimum values indicate, the most efficient mine's labor productivity was 33.7 times (626.2/18.6) larger than that of the most inefficient mine. This implies that shifting resources and production from inefficient mines to efficient ones could potentially raise average labor productivity of the coal industry.

\section{Table 7}

To confirm whether this potential productivity effect was realized, Table 8 compares the labor productivity of surviving, exiting and entering mines in each period. Looking at 1935-39, we find that the average labor productivity of exiting mines in 1935 was substantially lower than that of surviving mines, which implies that exit improved total average labor productivity. On the other hand, the average labor productivity of entering mines in 1939 was substantially lower than that of surviving mines in 1935, which implies that new entry reduced total average labor productivity. The condition that the labor productivity of new entrants was lower than that of survivors was common to the prewar period, 1930-35, but differences in labor productivity between the two groups grew in $1935-39$.

Table 8

Another channel through which mine dynamics had productivity implications is change in the share of surviving mines. Table 8 classifies surviving mines into two groups, namely the share-up group and the share-down group, to compare their labor productivity. Share-up (share-down) group refers to the group of mines whose share increased (decreased) in each period, and here share is measured by the number of workers. In 1935, the share-up group had a much higher average labor productivity than the share-down group, which implies that changes in the share of the surviving mines raised total average labor productivity. Furthermore, the difference between the two groups was substantially larger in 1935 than in 1930. During the late stage of the war, 1939-44, the relative labor productivity for the two groups was similar to that in 1935-39.

In summary, during the war, mine dynamics had productivity implications in two ways: whereas exit and share change had a positive impact on the total average labor productivity, entry had a negative impact. The next question, then, concerns the magnitudes of those impacts. To examine this issue, I decompose labor productivity 
change in each period using the formula of Baily et al. (1992) and Foster et al. (2001). That is, the change in labor productivity from year $t-1$ to year $t$ is decomposed into the following five components.

$\begin{array}{ll}\text { within effect } & \sum_{\mathrm{i}_{\in} \mathrm{S}} \theta_{\mathrm{it}-1} \Delta \mathrm{LP}_{\mathrm{i}, \mathrm{t}} \\ \text { between effect } & \sum_{\mathrm{i}_{\in} \mathrm{S}} \Delta \theta_{\mathrm{it}}\left(\mathrm{LP}_{\mathrm{it}-1}-\mathrm{LP}_{\mathrm{t}-1}\right) \\ \text { covariance effect } & \sum_{\mathrm{i}_{\in} \mathrm{S}} \Delta \theta_{\mathrm{it}} \Delta \mathrm{LP}_{\mathrm{i}, \mathrm{t}} \\ \text { exit effect } & \left.\sum_{\mathrm{i}_{\in} \mathrm{X} \theta_{\mathrm{it}-1}\left(\mathrm{LP}_{\mathrm{t}_{-}-1}-\mathrm{LP}_{\mathrm{it}-1}\right)}\right) \\ \text { entry effect } & \sum_{\mathrm{i}_{\in} \mathrm{N}} \theta_{\mathrm{it}}\left(\mathrm{LP}_{\mathrm{it}}-\mathrm{LP}_{\mathrm{t}_{-}}\right)\end{array}$

, where, LPit denotes labor productivity of mine $\mathrm{i}$ in year $\mathrm{t}$, and $\theta_{\text {it }}$ denotes share of mine $\mathrm{i}$ in year $\mathrm{t}$ in terms of the number of workers. $\mathrm{S}, \mathrm{X}$ and $\mathrm{N}$ refer to the sets of surviving, exiting and entering mines, respectively.

The within effect is the portion of productivity change caused by the labor productivity change of each mine, weighted by the initial share of each mine. The between effect represents the portion of labor productivity change caused by share change, weighted by the initial labor productivity deviation of each mine from the industry average. The covariance effect is the cross term of the above two effects. These three terms relate to the mines that survive from year $t-1$ to year $t$. The exit effect represents the portion caused by the labor productivity difference between exiting mines and the industry average in year $t-1$, while the entry effect represents the portion caused by the difference between the labor productivity of entering mines in year $t$ and the industry average in year $t-1$.

Table 9 reports the results of labor productivity change decomposition using the above formula. As seen in Figure 1, average labor productivity increased in the early 1930s and then declined until the end of the war. Table 9 indicates that the labor productivity increase in the early 1930s was basically caused by the within effect, namely the labor productivity increase of each mine. In the early stage of the war (1935 -39), the within effect became negative. At the same time, it is notable that the negative entry effect had substantial magnitude, and the between effect was positive and not negligible. In the late stage of the war, 1939-44, while the within effect continued to be negative and large, whereas magnitude of the negative entry effect declined and the between effect continued to be positive.

Table 9 
As mine-level TFP estimates are not available, the results in Table 9 cannot be directly compared with those in Table 5 , but some speculations are possible. Of the five components in Table 9, the between effect, the exit effect and the entry effects are attributable to the reallocation of resources in a broad sense. If we assume that the total resources for the coal industry are given, these effects are reflected in "TFP change within district" in Table 5. It is notable that this assumption nearly held during the war, because the government allocated resources to each industry according to the Material Mobilization Plan, as mentioned in Section 2. If this is the case, the large negative TFP growth in Table 5 at least partly reflects the large negative entry effect in this period, while the reduction in negative TFP growth in Table 5 reflects a decline of the negative entry effect together with continuation of the positive between effect.

Finally, as was shown in Table 9, within effects accounted for the largest portion of the labor productivity decline during the war. A closer look at the mine-level data can help us understand more about this phenomenon. Table 10 lists the mines with the largest negative within effects for the periods $1935-39$ and 1939-44. As seen, most of these mines increased their share in terms of workers, and had a much higher labor productivity than the average in Table 7. The government and the Coal Control Association made great efforts to expand the labor force, which was a relatively abundant resource, of efficient mines. As a result, labor productivity of those mines declined sharply, because of the relative shortage of other resources and deterioration of the vein. The same situation also explains the large negative covariance effect in this period. This implies that leveling of labor productivity was attributable to the resource reallocation. To illustrate that, Figure 4 depicts the changes in the number of workers and labor productivity for mines in the upper and lower tertiles in terms of labor productivity in 1935. It is clear that workers were concentrated in the upper tertile mines, and the labor productivities of these two groups of mines converged. That labor productivity leveled is also confirmed by Table 7, which shows a sharp decline in the the standard deviation from 1935 to 1944.

Table 10, Figure 4

\section{Concluding remarks}

In the 1930s and 1940s, the Japanese coal industry experienced huge fluctuations in production and labor productivity. In this paper, I explored the micro-aspects of labor productivity change in the coal industry during World War II, using district -level and mine-level data compiled from official statistics and the original 
documents of the Coal Control Association. During this period, the coal industry was characterized by dynamic changes in market structure. That is, a number of mines entered and exited the industry, and the shares of incumbent mines also changed substantially. These mine dynamics had substantial productivity implications. In the early stage of the war, many inefficient mines entered the industry, which lowered average labor productivity considerably. However, the government and the Coal Control Association implemented a policy to concentrate resources and production on efficient mines during the war, which curbed the decline in average labor productivity and TFP. Despite the deteriorating environment, coal production in Japan was maintained fairly well during the war. One of the conditions that made this possible was the policy of resource reallocation.

\section{References}

Baily, M. N., C. Hulten, and D. Cambell. 1992. Productivity dynamics in manufacturing plants. Brooking Papers on Economic Activity, Microeconomics: 187-249.

Bank of Japan. 1966. Meiji iko honpo shuyo keizai tokei (Hundred-year statistics of the Japanese economy). Tokyo: Bank of Japan.

Dunne, T., M. Roberts, and L. Samuelson. 1988. Patterns of firm entry and exit in U.S. manufacturing industries. Rand Journal of Economics 19(4): 495-515.

Dunne, T., M. Roberts, and L. Samuelson. 1989. The growth and failure of U.S. manufacturing plants. Quarterly Journal of Economics 104: 671-98.

Ellerman, D., T. M. Stoker, and E. R. Berndt. 2001. Sources of productivity growth in American coal industry: 1972-95. In C. R. Hulten, E. R. Dean, and M. J. Harper eds., New development in Productivity analysis. Chicago: The University of Chicago Press.

Foster. L., J. Haltiwanger, and C. J. Keizan. 2001. Aggregate productivity growth: lessons from microeconomic evidence. In C. R. Hulten, E. R. Dean, and M. J. Harper eds., op cit..

Griliches, Z., and H. Regev. 1995. Productivity and firm turnover in Israeli industry: 1979-1988. Journal of Econometrics 65: 175-203.

Nakamura, T. 1983. Economic Growth in Prewar Japan. New Haven: Yale University Press.

Nezu, T. ed. 1958. Sekitan kokka tosei shi (History of state control on coal). Tokyo: Nihon Keizai Kenkyujo.

Okazaki, T. 1987. Senji keikaku keizai to kakaku tosei (Wartime economic planning and 
price control). In Kindai Nihon Kenkyukai ed. Senji keizai. Tokyo: Yamakawa Shuppansha.

Okazaki, T. 2002. Keisha seisan to nihon keizai no fukko. In Akira Hara ed., Fukkoki no Nihon keizai (Japanese economy in the period of economic recovery). Tokyo: Tokyo Daigaku Shuppannkai.

Okazaki, T., and M. Okuno-Fujiwara. 1999. Japan's present-day economic system and its historical origins. In T. Okazaki and M. Okuno-Fujiwara eds. The Japanese economic system and its historical origins. New York: Oxford University Press

Nihon Sekitan Kyokai. 1950, 1957. Sekitan tokei soran (Statistical handbook of the coal industry). Tokyo: Nihon Sekitan Kyokai.

Toyo Keizai Shinposha. 1991. Kanketsu Showa kokusei soran (Statistical handbook of Showa Japan) vol. 1. Tokyo: Toyo Keizai Shinposha. 
Figure 1 Coal production and labor productivity in Japan $(1930=100)$

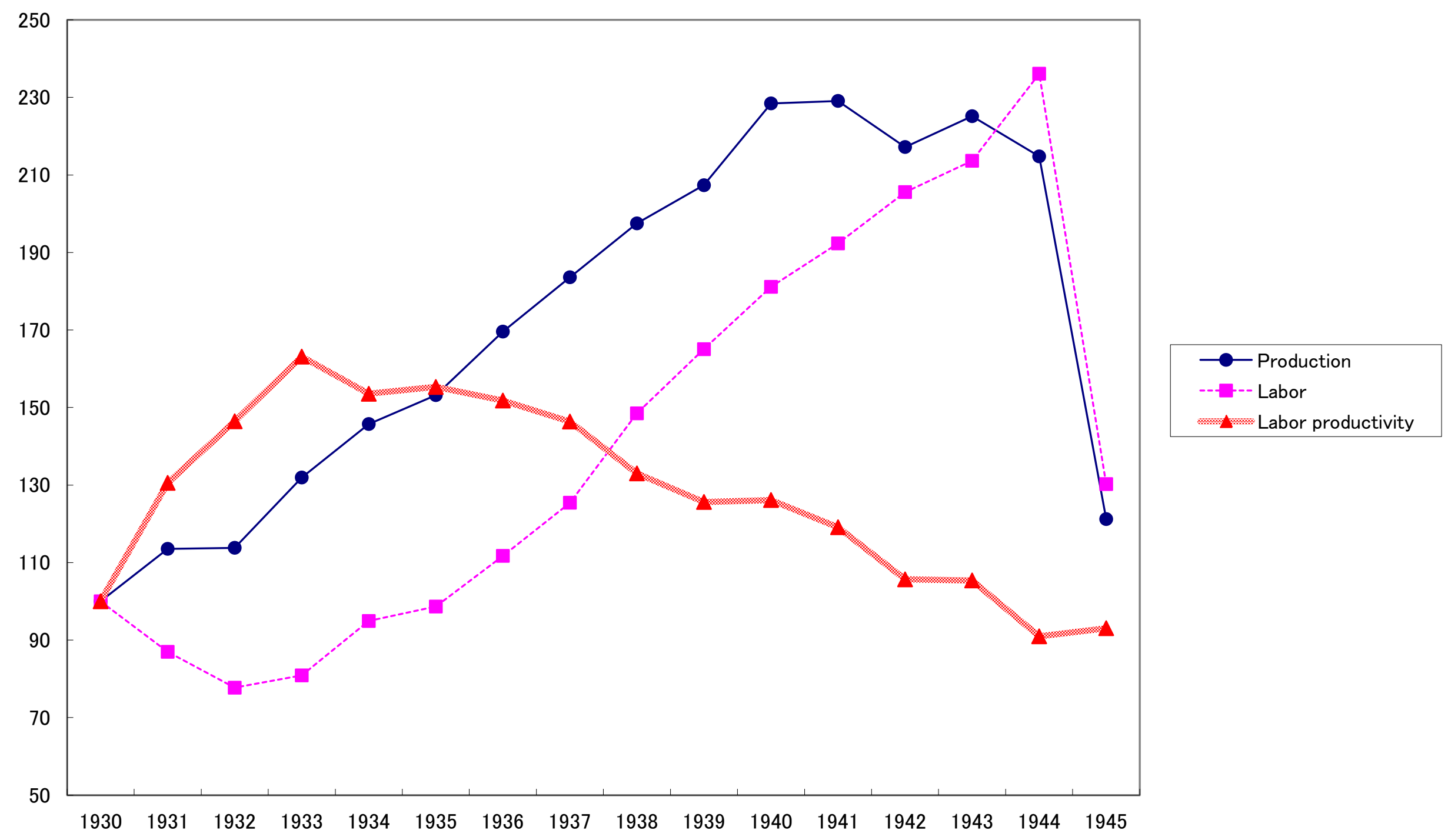


Figure 2 Coal price and WPI $\quad(1934-36$ average $=100)$

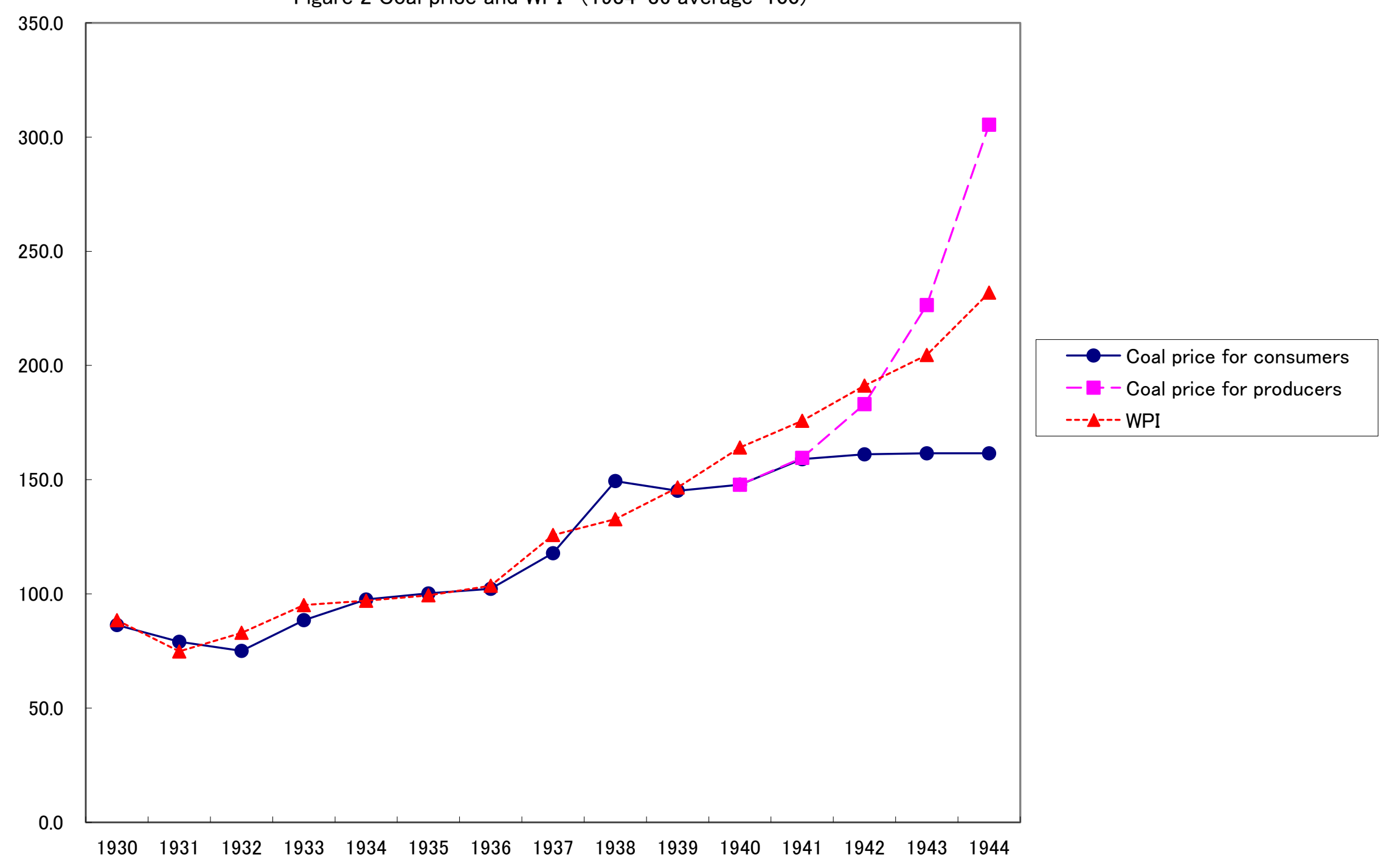


Figure 3 Material inputs-labor ratios $(1930=100)$

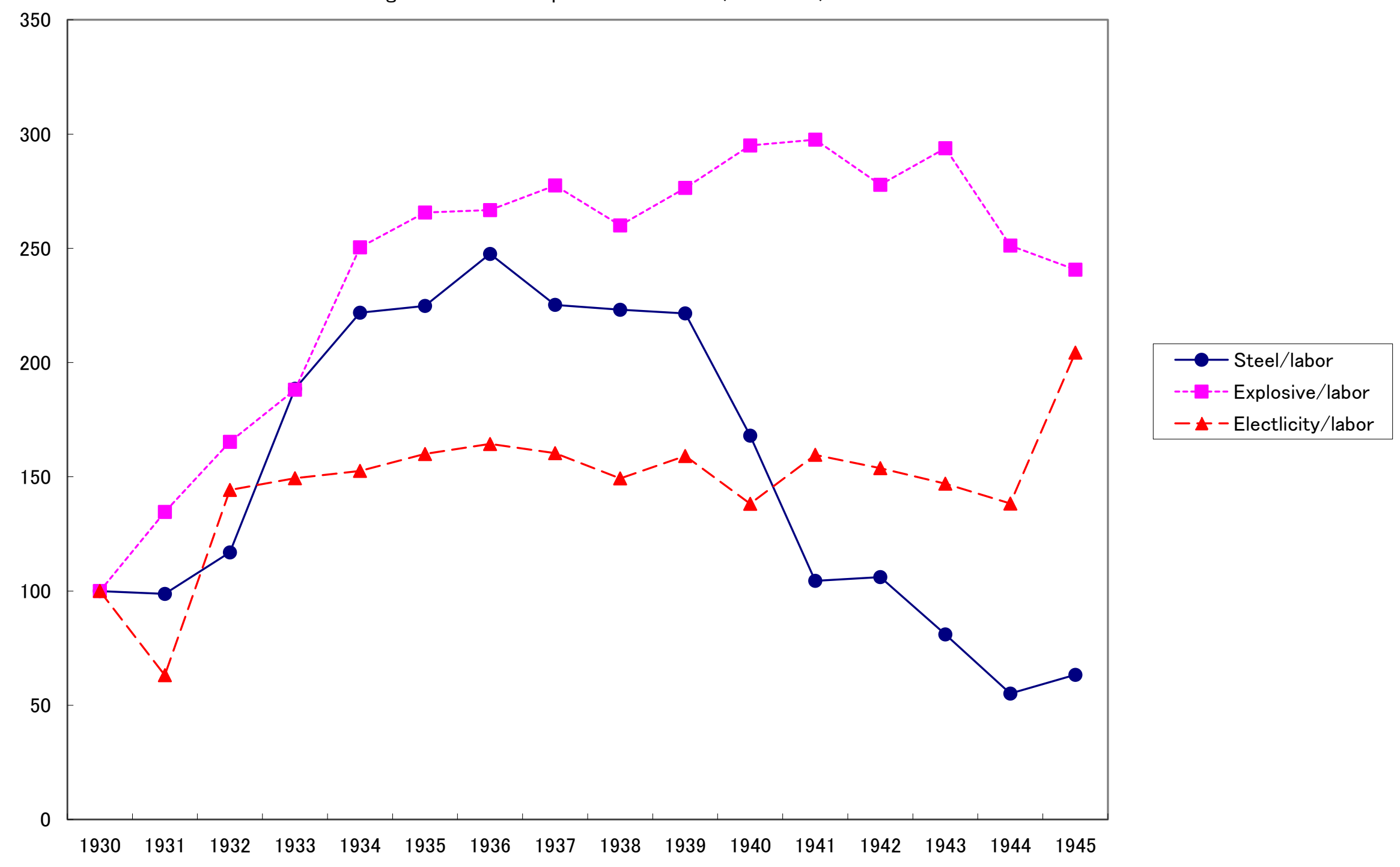


Figure 4 Concentration of labor force and leveling of labor

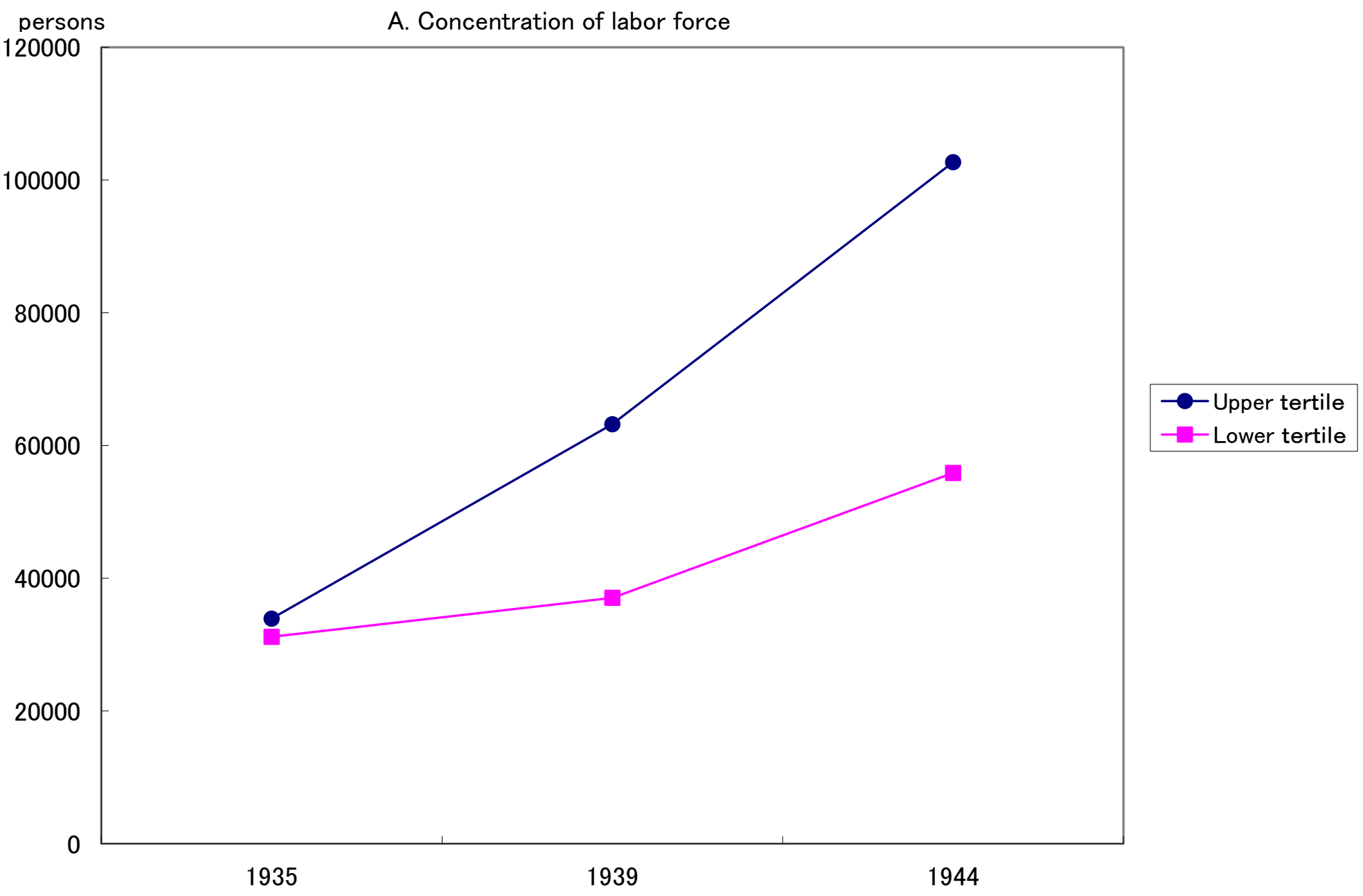




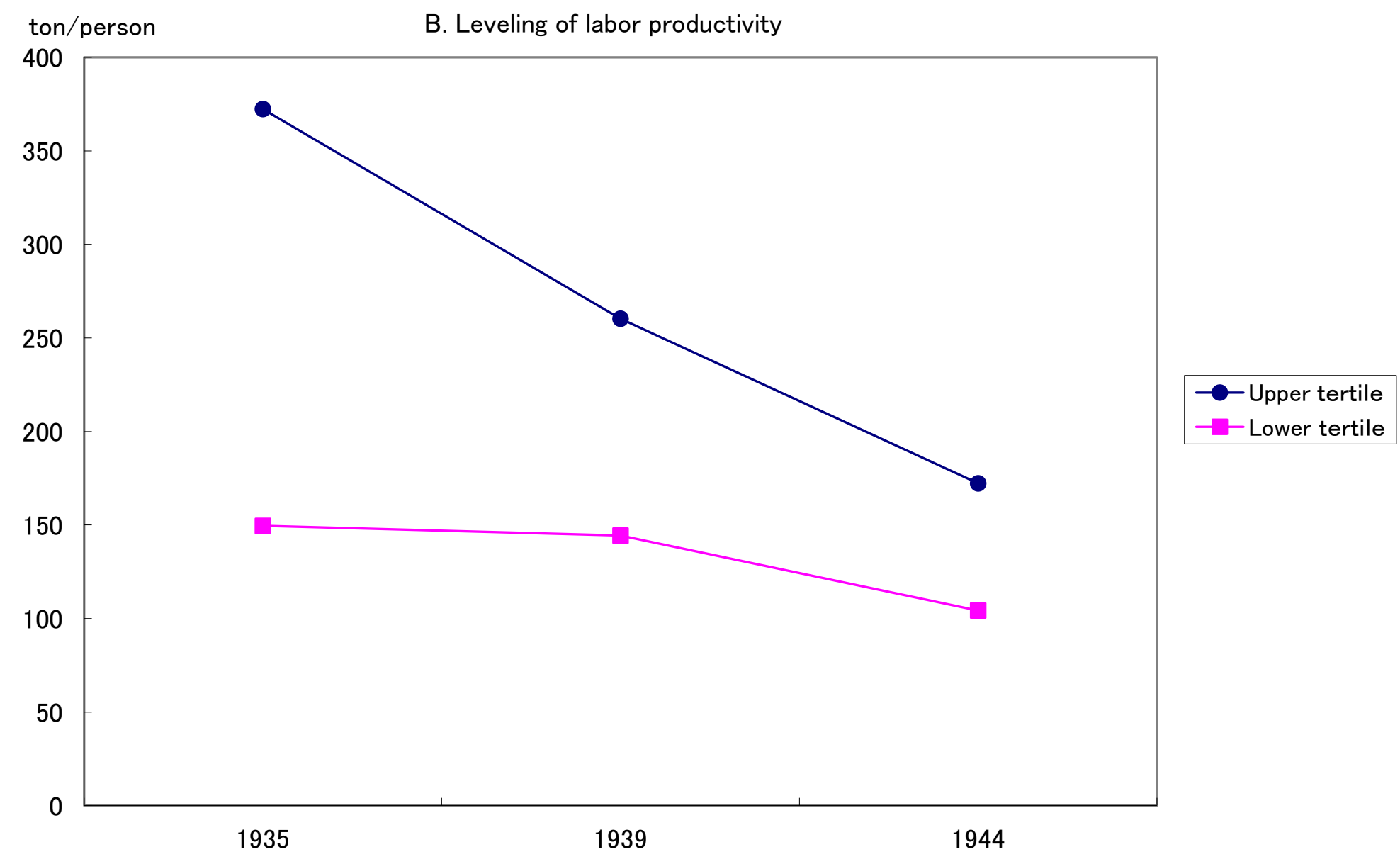


Table 1 Long-term plans for coal production expansion

\begin{tabular}{|c|c|c|c|c|c|}
\hline & $\begin{array}{l}\text { Prediction by } \\
\text { Showa Sekitan } \\
\text { June } 1937 \\
\end{array}$ & 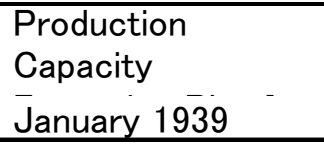 & $\begin{array}{l}\text { Production Capacity } \\
\text { Expansion Plan II } \\
\text { June } 1942 \\
\end{array}$ & $\begin{array}{l}\text { Practical plan } \\
\text { for each year }\end{array}$ & $\begin{array}{l}\text { Actual } \\
\text { Production }\end{array}$ \\
\hline 1937 & 50,810 & & & & 45,258 \\
\hline 1938 & 54,450 & 58,363 & & & 48,864 \\
\hline 1939 & 58,700 & 65,803 & & 53,896 & 51,111 \\
\hline 1940 & 61,550 & 71,725 & & 58,000 & 56,313 \\
\hline 1941 & 65,490 & 78,182 & & 59,000 & 56,472 \\
\hline 1942 & & & 73,300 & 57,000 & 53,540 \\
\hline 1943 & & & 75,300 & 55,000 & 55,500 \\
\hline 1944 & & & 77,600 & 58,200 & 52,945 \\
\hline 1945 & & & 82,000 & 20,566 & 29,879 \\
\hline
\end{tabular}

Source: Nezu ed. (1958), p.101; Kokumin Keizai Kenkyu Kyokai and Kinzoku Kogyo Chosakai (1946); Ministry of International Trade and Industry. Honpo kogyo no susei, 1955 issue. 
Table 2 District-level data on coal production and inputs

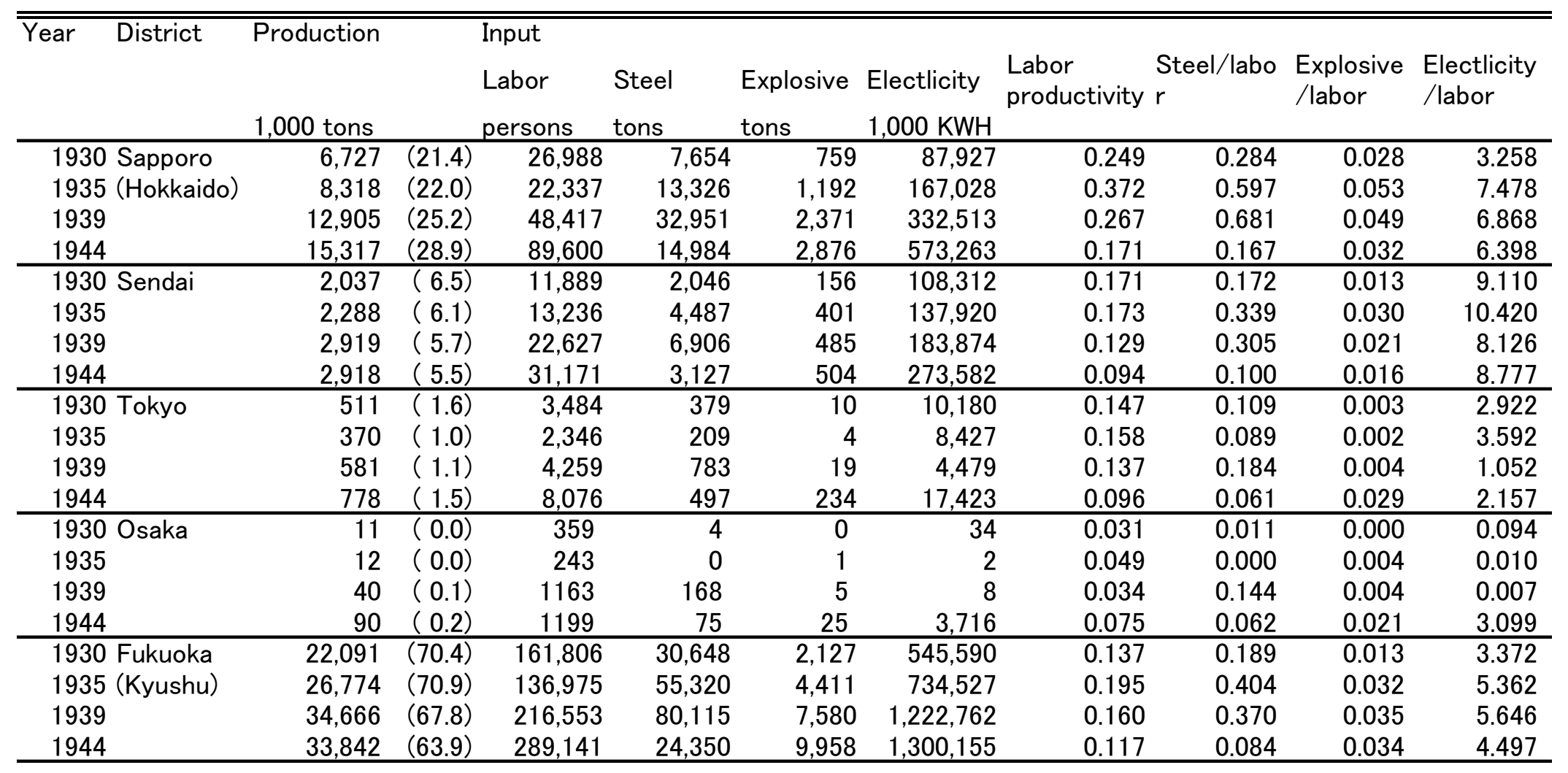

Note: District refers to the area that each mine supervising bureau took charge of. See the text.

Percentage in parentheses. 
Table 3 Basic statistics of district-level observations

\begin{tabular}{|c|c|c|c|c|c|}
\hline & Obs. & Mean & Srdev. & Max. & Min. \\
\hline $\ln (\mathrm{Y} / \mathrm{L})$ & 75 & 4.934 & 0.599 & 5.938 & 3.410 \\
\hline In(STEEL/L) & 75 & -1.842 & 0.997 & -0.385 & -5.493 \\
\hline In(EXPLOSIVE/L) & 75 & -4.139 & 1.010 & -2.930 & -7.029 \\
\hline $\ln ($ ELECTRICITY/L) & 75 & 7.377 & 3.153 & 9.378 & -5.814 \\
\hline
\end{tabular}


Table 4 Estimation result of production function

\begin{tabular}{lrl}
\hline \hline \multicolumn{2}{l}{ Dependent variable: $\ln (\mathrm{Y} / \mathrm{L})$} & \\
\hline $\ln (\mathrm{STEEL} / \mathrm{L})$ & 0.115 & $(3.09) * * *$ \\
In(EXPLOSIVE/L) & 0.194 & $(3.85) * * *$ \\
In(ELECTRICITY/L) & 0.035 & $(2.72) * * *$ \\
Sendai & -0.437 & $(-7.84) * * *$ \\
Tokyo & -0.054 & $(-0.41)$ \\
Osaka & -0.913 & $(-5.91) * * *$ \\
Fukuoka (Kyushu) & -0.408 & $(-8.69) * * *$ \\
1931 & 0.375 & $(2.96) * * *$ \\
1932 & 0.279 & $(2.96) * * *$ \\
1933 & 0.230 & $(2.09) * *$ \\
1934 & 0.096 & $(1.05)$ \\
1935 & 0.129 & $(1.31)$ \\
1936 & 0.149 & $(1.53)$ \\
1937 & 0.087 & $(0.96)$ \\
1938 & -0.150 & $(-1.50)$ \\
1939 & -0.219 & $(-2.08) * *$ \\
1940 & -0.229 & $(-1.94) *$ \\
1941 & -0.245 & $(-2.07) * *$ \\
1942 & -0.246 & $(-2.01) * *$ \\
1943 & -0.288 & $(-2.42) * *$ \\
1944 & -0.356 & $(-2.81) * * *$ \\
Constant & 6.078 & $(26.47) * * *$ \\
$\mathrm{R}^{2}$ & 0.950 & \\
\hline
\end{tabular}

Note: Heteroschedasticity robust $\mathrm{t}-\mathrm{values}$ are in parentheses.

$* * *$ statistically significant at $1 \%$ level.

** statistically significant at $5 \%$ level.

* statistically significant at $10 \%$ level. 
Table 5 Decomposition of labor productivity change

\begin{tabular}{|c|c|c|c|c|}
\hline & & $1930-35$ & $1935-39$ & $1939-44$ \\
\hline \multirow[t]{8}{*}{ A } & Total & 0.391 & -0.329 & -0.294 \\
\hline & Contribution pf input-labor ratio & 0.265 & 0.005 & -0.179 \\
\hline & STEEL/L & 0.084 & -0.003 & -0.161 \\
\hline & EXPLOSIVE/L & 0.164 & 0.008 & -0.014 \\
\hline & ELECTRICITY/L & 0.017 & -0.001 & -0.004 \\
\hline & Contribution of TFP & 0.126 & -0.334 & -0.115 \\
\hline & TFP change within district & 0.129 & -0.348 & -0.137 \\
\hline & Reallocation between districts & -0.003 & 0.014 & 0.022 \\
\hline \multirow[t]{8}{*}{ B } & Total & 0.395 & -0.329 & -0.311 \\
\hline & Contribution pf input-labor ratio & 0.266 & 0.005 & -0.190 \\
\hline & STEEL/L & 0.086 & -0.001 & -0.162 \\
\hline & EXPLOSIVE/L & 0.162 & 0.007 & -0.022 \\
\hline & ELECTRICITY/L & 0.018 & 0.000 & -0.005 \\
\hline & Contribution of TFP & 0.129 & -0.334 & -0.121 \\
\hline & TFP change within district & 0.129 & -0.348 & -0.137 \\
\hline & Reallocation between districts & 0.000 & 0.014 & 0.016 \\
\hline
\end{tabular}

Note: A Weighetd by number of workers.

B: Weighted by coal production. 
Table 6 Entry and exit of coal mines

\begin{tabular}{|c|c|c|c|c|c|}
\hline \multicolumn{2}{|l|}{ A. $1930-1935$} & \multicolumn{2}{|l|}{1930} & \multicolumn{2}{|l|}{1935} \\
\hline \multirow[t]{3}{*}{ Total } & Number of mines & 156 & $(100.0)$ & 197 & $(100.0)$ \\
\hline & Number of workers (persons) & 198,598 & $(100.0)$ & 166,516 & $(100.0)$ \\
\hline & Production (1,000 tons) & 30,955 & $(100.0)$ & 37,278 & $(100.0)$ \\
\hline \multirow[t]{3}{*}{ Survive } & Number of mines & 121 & $(77.6)$ & 121 & ( 61.4) \\
\hline & Number of workers (persons) & 181,372 & ( 91.3) & 142,665 & ( 85.7) \\
\hline & Production (1,000 tons) & 28,935 & (93.5) & 33,889 & $(90.9)$ \\
\hline \multirow[t]{3}{*}{ Exit } & Number of mines & 35 & ( 22.4) & - & - \\
\hline & Number of workers (persons) & 17,226 & ( 8.7) & - & - \\
\hline & Production $(1,000$ ton & 2,019 & $6.5)$ & - & - \\
\hline \multirow[t]{3}{*}{ Entry } & Number of mines & - & - & 76 & $(38.6)$ \\
\hline & Number of workers (persons) & - & - & 23,851 & ( 14.3) \\
\hline & Production ( 1,000 ton & - & - & 3,389 & $(9.1)$ \\
\hline B. $1935-1939$ & & 1935 & & 1939 & \\
\hline \multirow[t]{3}{*}{ Total } & Number of mines & 197 & $(100.0)$ & 280 & (100.0) \\
\hline & Number of workers (persons) & 166,516 & $(100.0)$ & 270,250 & $(100.0)$ \\
\hline & Production (1,000 tons) & 37,278 & $(100.0)$ & 49,817 & $(100.0)$ \\
\hline \multirow[t]{3}{*}{ Survive } & Number of mines & 136 & $(69.0)$ & 136 & $(48.6)$ \\
\hline & Number of workers (persons) & 144,860 & $(87.0)$ & 217,528 & ( 80.5$)$ \\
\hline & Production ( 1,000 tons) & 33,720 & (90.5) & 42,756 & ( 85.8) \\
\hline \multirow[t]{3}{*}{ Exit } & Number of mines & 61 & $(31.0)$ & - & - \\
\hline & Number of workers (persons) & 21,656 & ( 13.0) & - & - \\
\hline & Production (1,000 tons) & 3,558 & ( 9.5) & - & - \\
\hline \multirow{3}{*}{ Entry } & Number of mines & - & - & 144 & ( 51.4) \\
\hline & Number of workers (persons) & - & - & 52,722 & ( 19.5) \\
\hline & Production $(1,000$ tons & - & - & 7,061 & (14.2) \\
\hline C. $1939-1944$ & & 1939 & & 1944 & \\
\hline \multirow{3}{*}{ Total } & Number of mines & 280 & $(100.0)$ & 183 & $(100.0)$ \\
\hline & Number of workers (persons) & 270,250 & (100.0) & 351,880 & $(100.0)$ \\
\hline & Production (1,000 tons) & 49,817 & $(100.0)$ & 49,667 & $(100.0)$ \\
\hline \multirow[t]{3}{*}{ Survive } & Number of mines & 148 & $(52.9)$ & 148 & $(80.9)$ \\
\hline & Number of workers (persons) & 224,060 & ( 82.9) & 323,765 & (92.0) \\
\hline & Production (1,000 tons) & 42,795 & $(85.9)$ & 46,019 & $(92.7)$ \\
\hline \multirow[t]{3}{*}{ Exit } & Number of mines & 132 & (47.1) & - & - \\
\hline & Number of workers (persons) & 46,190 & ( 17.1) & - & - \\
\hline & Production (1,000 tons) & 7,022 & ( 14.1) & - & - \\
\hline \multirow[t]{3}{*}{ Entry } & Number of mines & - & - & 35 & ( 19.1) \\
\hline & Number of workers (persons) & - & - & 28,115 & $(8.0)$ \\
\hline & Production ( 1,000 tons) & - & - & 3,648 & $(7.3)$ \\
\hline
\end{tabular}

Source: see the text. 
Table 7 Heterogeneity of coal mines in terms of productivity and production

\begin{tabular}{lrrrrrr}
\hline \hline & \multicolumn{2}{c}{ Average } & \multicolumn{1}{c}{ Median } & \multicolumn{1}{c}{ Stdev. } & \multicolumn{1}{l}{ Max. } & Min. \\
\hline Productivity & 1930 & 159.6 & 144.0 & 71.3 & 482.9 & 37.4 \\
(tons/person) & 1935 & 199.8 & 170.6 & 118.1 & 871.8 & 19.3 \\
& 1939 & 164.0 & 147.2 & 82.4 & 626.2 & 18.6 \\
& 1944 & 129.0 & 124.2 & 51.7 & 501.4 & 15.4 \\
\hline Production & 1930 & 197.2 & 96.8 & 282.5 & 2269.5 & 10.4 \\
(1,000 tons) & 1935 & 188.3 & 84.2 & 294.7 & 2488.5 & 10.0 \\
& 1939 & 177.3 & 50.2 & 345.5 & 3362.4 & 10.0 \\
& 1944 & 269.3 & 117.6 & 440.8 & 4031.2 & 10.1 \\
\hline
\end{tabular}


Table 8 Productivity implication of mine dynamics

\begin{tabular}{|c|c|c|}
\hline A. $1930-1935$ & 1930 & 1935 \\
\hline Total & 155.9 & 223.9 \\
\hline Survive & 159.5 & 237.5 \\
\hline Share up & 166.4 & 202.4 \\
\hline Share down & 154.6 & 287.0 \\
\hline Exit & 117.2 & - \\
\hline Entry & - & 142.1 \\
\hline B. $1935-1939$ & 1935 & 1939 \\
\hline Total & 223.9 & 184.3 \\
\hline Survive & 232.8 & 196.6 \\
\hline Share up & 286.8 & 210.4 \\
\hline Share down & 194.4 & 178.8 \\
\hline Exit & 164.3 & - \\
\hline Entry & - & 133.9 \\
\hline C. $1939-1944$ & 1939 & 1944 \\
\hline Total & 184.3 & 140.7 \\
\hline Survive & 191.0 & 142.1 \\
\hline Share up & 214.3 & 144.0 \\
\hline Share down & 172.4 & 136.1 \\
\hline Exit & 152.0 & - \\
\hline Entry & - & 124.0 \\
\hline
\end{tabular}


Table 9 Decomposition of productivity change

\begin{tabular}{lrrrcrr}
\hline \hline & \multicolumn{1}{c}{ Total } & \multicolumn{1}{c}{ Within } & Between & Covariance Exit & \multicolumn{2}{c}{ Entry } \\
\hline $1930-35$ & 68.0 & 84.9 & 3.2 & -21.4 & 3.4 & -2.0 \\
$1935-39$ & -39.5 & -32.4 & 13.8 & -11.1 & 7.8 & -17.5 \\
$1940-44$ & -43.6 & -39.4 & 10.9 & -15.9 & 5.5 & -4.8 \\
\hline
\end{tabular}


Table 10 Break down of within effect (Mines with largest negative within effects)

\begin{tabular}{|c|c|c|c|c|c|c|c|c|c|}
\hline \multirow[t]{2}{*}{ Period } & \multirow[t]{2}{*}{ Name } & \multirow[t]{2}{*}{ District } & \multirow[t]{2}{*}{ Within effect } & \multicolumn{2}{|l|}{ Productivity } & \multicolumn{2}{|c|}{ Worker share } & \multicolumn{2}{|c|}{ Number of workers } \\
\hline & & & & First year & Last year & First year & Last year & First year & Last year \\
\hline \multirow[t]{5}{*}{$1935-39$} & Miike & Fukuoka & -3.84 & 239 & 178 & 0.0624 & 0.0699 & 10,396 & 18,898 \\
\hline & Onoura & Fukuoka & -2.34 & 276 & 197 & 0.0295 & 0.0303 & 4,917 & 8,199 \\
\hline & Akaike & Fukuoka & -2.14 & 215 & 19 & 0.0109 & 0.0104 & 1,819 & 2,812 \\
\hline & Sakito & Fukuoka & -1.98 & 355 & 232 & 0.0161 & 0.0176 & 2,684 & 4,762 \\
\hline & Mitsui Tagawa & Fukuoka & -1.93 & 261 & 192 & 0.0277 & 0.0379 & 4,613 & 10,253 \\
\hline \multirow{3}{*}{$1939-44$} & Yubari & Sapporo & -2.24 & 315 & 191 & 0.0180 & 0.0333 & 4,869 & 11,701 \\
\hline & Onoura & Fukuoka & -1.93 & 197 & 133 & 0.0303 & 0.0282 & 8,199 & 9,909 \\
\hline & Mitsui Tagawa & Fukuoka & -1.89 & 192 & 142 & 0.0379 & 0.0378 & 10,253 & 13,285 \\
\hline
\end{tabular}

